\author{
J HUBERT LACEY
}

All clinicians are a product of their own age. Throughout the centuries they have faced similar signs and symptoms, but their interpretation and understanding of them has been coloured by the beliefs of the society in which they have lived.

The conception of what we now call anorexia nervosa perhaps provides an example of this. Although the term was first coined 130 years ago, it is only in recent years that the diagnostic criteria have become common medical knowledge. Certainly, with increasing diagnosis and, most probably, increasing incidence, the impression is gained that the disorder is fairly "new," a product of civilisation and increasing affluence. Nevertheless, a thousand years ago a religious cult developed in Europe which could indicate that the disease was not only known to the ecclesiastical authorities but that the clinical features, psychopathology, and even treatment were understood.

The Legend of St Wilgefortis, or Uncumber, is curious-so curious that it has been dismissed in recent times as "a worthless romance abounding in absurdities," or as "a pious fiction to end all pious fictions." 2 Such views of hagiographers, however, ignore the possibility that St Wilgefortis was perhaps the first written attempt to understand the pathogenesis of anorexia nervosa: the symptoms and psychopathology presented in the religious jargon of her day.

\section{Pursuit of thinness}

The consensus of present medical opinion is that anorexia nervosa is psychologically determined. Crisp ${ }^{3}$ states that the pathognomonic feature of the condition is an irrational fear of normal body weight. Bruch" calls this concept a "pursuit of thinness," while Russell ${ }^{5}$ refers to it as "a morbid fear of fatness" and claims it as one of three necessary criteria for diagnosis; the others being firstly, behaviour aimed at weight loss and, secondly, a resultant endocrinological disorder.

The weight loss of anorexia nervosa is achieved not by general starvation but by specific carbohydrate avoidance, ${ }^{56}$ and successful treatment depends, in part, on a refeeding programme that contains adequate and normal supplies of carbohydrate foods.

The endocrine disorder is secondary to weight loss and manifest as amenorrhoea, but in some patients the hormonal imbalance is such that hair develops on the upper lip and chin. In addition, lanugo hair grows on the back, arms, legs, and side of the face. Individual variation is considerable, but the more emaciated the patient the more the hair grows. ${ }^{7}$ The downy hair is believed to help temperature regulation in the absence of adequate subcutaneous fat tissue. Head hair is apt to be thin and may sometimes fall out, tending, therefore, to further emphasise any other extraneous facial hair. ${ }^{8}$

\section{St Wilgefortis}

Many clinicians have noted the tendency of anorectics to be striving girls with high ethical and moral standards. The condition tends to be particularly prevalent among the higher social classes. ${ }^{9}$ It arises during early adolescence and appears to

\footnotetext{
Academic Department of Psychiatry, St George's Hospital Medical School, London SW17 ORE
}

J HUBERT LACEY, MB, MRCPSYCH, senior lecturer and honorary consultant be generated by an inability to cope with the demands and fears of adult sexuality, ${ }^{3410}$ and thus it can be construed as a return, physiologically and psychologically, to a prepubescent state.

How then do these data relate to a thousand-year-old legend ? According to the legend, St Wilgefortis was the seventh daughter of the King of Portugal. ${ }^{11} \mathrm{Her}$ father was a tyrannical man known for his cruelty and grossness. ${ }^{12}$ Certainly, his daughter was not enamoured by him and was horrified when she learnt of his plan to marry her to a Saracen King of Sicily. Wilgefortis had already made a vow of virginity and had planned to give her life to God-not man. Some versions of the legend suggest that she

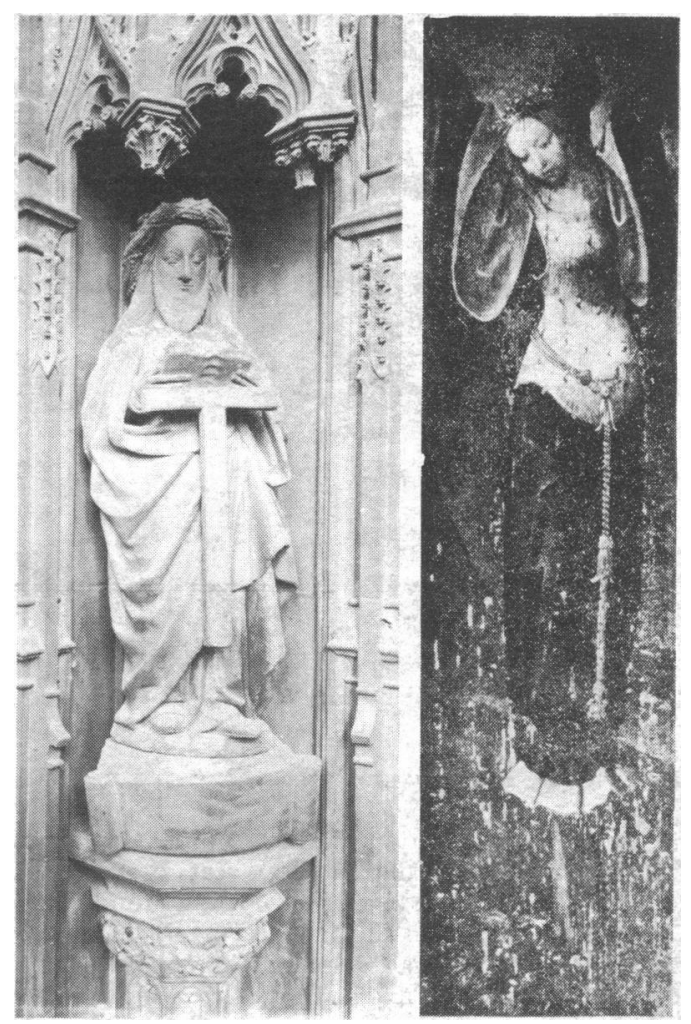

Left: Statue of St Wilgefortis in Henry VIII's Chapel, Westminster Abbey. "Prayed to by women to the derision of men." Right: Part of an early triptych (Flemish). Reproduced by courtesy of, respectively the Dean and Chapter of Westminster and the British Library.

received incestuous attention from her father. Whatever the pressure, however, "in order to preserve her virginity"13 and to avoid marriage, she prayed to God for help. The intensity of her prayer impressed observers. She became ascetic, overcoming her appetite, as an expression of selfless love of God and enhancement of spiritual development. "She begged the Lord to deprive her of all beauty and God granted her prayer"14 by causing her to develop a hairy body and grow a beard. The King of Sicily withdrew his suit, and Wilgefortis's father, in an uncontrolled rage, had her crucified. While on the cross she prayed to all to remember "the passion that encumbrance all women." Classicists would claim this alludes to "things suffered" (passions) by women which would, of course, include menstruation. In addition, she claimed that she had been "liberated" from 
"worldly care" (see below) and prayed that any woman who used her as a medium of prayer should be similarly blessed as her. ${ }^{15}$

\section{Cult in Europe}

The legend is old. Political references in the story suggest that Wilgefortis lived some time between $\mathrm{AD} 700$ and 1000 . The legend remained local to Portugal until about 1200 onwards, when there was a sudden "spread" of the cult around Europe. Our saint changes her name, being St Ontkommena in the Netherlands, St Kummernis in parts of Germany, St Livrade in Gascony, and St Liberata in Spain. ${ }^{1}$ The diversity of her name at a time when communication was minimal has been the subject of comment. ${ }^{14}$ It is odd that there was a sudden spread of a legend of a saintly, female, virgin martyr who avoids her sexuality by growing hair. Unless, that is, Wilgefortis is not one saint with many names but an account of many girls with different names, but similar clinical history, developing a similar illness throughout Europe.

Our knowledge of the early life of Wilgefortis is sketchy. This would not be surprising if the legend becomes interwoven with clinical material from different cases and sources. What is consistent is that she was considered a thoughtful girl who sought guidance from the Church, and rejected the "wordly interests" of her sisters. The Church in later years saw her as a girl of high moral standards, and applauded her tendency to seclude herself in prayer and her "desire for virginity,"16 her asceticism, and wasting.

In the Europe of the dark ages it was customary that declarations of marriage should be made at the time of menarche. Wilgefortis was therefore a young girl, having just approached puberty and coming from a relatively affluent background-the daughter of a king being social class I indeed! There is emphasis on the cultural and ethical differences between Wilgefortis and her pagan father as well as, as mentioned above, the suggestion, from some sources, of incest. This emphasis culminates in Wilgefortis's crucifixion by her father with the support and encouragement of her family, the symbolism of which would not be lost on the anorectic patient of today. ${ }^{41017}$

\section{St Uncumber in Billingsgate}

To understand the cult we need to recall the desolation and ignorance of the dark ages. Medical practice was, at times, banned by the Church. ${ }^{18}$ What knowledge there was was in the hands of clerics or monks, usually far removed in training from the sophistication of even contemporary Islamic medicine. Portugal at that time was under constant Moorish and pagan military pressure, and thus it is unsurprising that the aetiology of the anorexia should be incorporated into a rejection of Islam and the clinical features of the condition interpreted in the religious jargon of the day. Their understanding of the condition is indicated by the meaning of the names given to these saintly girls. Some called her a strong virgin, or virgo fortis (Wilgefortis). As St Livrade, she was the saint who liberates from care or Kommer (hence St Ontcommer or St Kummernis). In Germany her loss of weight and female shape and fat distribution led her to be considered as a saint who changed her sex to being a man. More generally, however, she was seen as a woman who had divested herself of female "care" or problems. Thus in Portugal and Spain she became a protectress (St Liberata) of women with sexual problems, particularly problems associated with childbirth.

This view of her was also held in England, where the cult arrived late. She had a statue erected in her honour in Billingsgate and was called St Uncumber. Contemporary sources referred to her as a female saint prayed to exclusively by women to the derision of men. Women who had difficult, troublesome, or wayward husbands and who wished to "uncumber" (sic) themselves of them ${ }^{14}$ prayed through her, for she was seen as a woman who had successfully resisted both a husband and father under extraordinary pressure.

It was customary at that time in Billingsgate to offer a bowl of oats to her statue when a woman pleaded her case before the saint. Votive offerings of food were not common in England, and our recognition now that anorexia nervosa is essentially an avoidance of carbohydrate leads to fascinating speculation of how this custom developed. Others, notably Sir Thomas More, derided the custom and the "ignorant women" who sought her help: "whereof I cannot perceive the reason, but if it be because she should provide a horse for an evil husband to ride to the devil upon, for that is the thing that she is so sought for, as they say. In so much that women have, therefore, changed her name and instead of St Wilgefortis do call her St Uncumber because that they reckon that for a peck of oats she will not fail to uncumber them of their husbands." 1114

The ascetic movement with its emphasis on fasting, purging, insomnia, and heroic hyperactivity is all a part of the struggle against the flesh advocated by the early austere Christians. The cult of St Wilgefortis is a later example, and no claim is being made here that she is the first recorded case of anorexia nervosa. (After all, in the fourth century St Jerome, writing to his protégé Eustochium, a young well-born girl, said, "Let your companions be women, pale and thin with fasting such as daily, say, with true earnestness 'I have a desire to depart and be with Christ'."'18 Eustochium's sister, Blessila, also under St Jerome's tutelage, died of just such a regimen of fasting and is possibly the earliest recorded victim of anorexia.) What is unique about this legend, however, is that not only are the features of the disorder clearly described, but the underlying psychological fears that generated them are sensitively understood. What we now see as a disease produced by a complex inter-play of emotional, social, family, and existential dynamics was viewed in premediaeval Europe as a miracle: an attempt by minds unenlightened by the Renaissance to explain in a series of well-born girls an overwhelming fear of the implications of sexuality and marriage.

\section{References}

${ }^{1}$ Benedictine Monks, Ramsgate, eds. Book of saints. 5th ed. London: A \& C Black, 1966.

2 Thurston H, Attwater D, eds. Butler's lives of the saints. Vol 3. London: Burns \& Oates, 1956.

3 Crisp AH. Anorexia nervosa. Hospital Medicine 1967;1:713-8.

4 Bruch H. Eating disorders. London: Routledge and Kegan Paul, 1974.

${ }^{5}$ Russell GFM. Anorexia nervosa-its identity as an illness and its treatment. In : Price JH, ed. Modern trends in psychological medicine. Vol 2. London: Butterworth, 1970:131-64.

${ }^{6}$ Crisp AH. Clinical aspects of anorexia. Proc Nutr Soc 1967;26:32.

' Dally P, Gomez J. Anorexia nervosa. London: Heinemann, 1979.

${ }^{8}$ Edwards A, Rook A. Androgenic syndromes. In: Edwards A, Rook A, eds. Recent advances in dermatology. Edinburgh: Churchill, 1980.

${ }^{9}$ Crisp AH. Anorexia nervosa: let me be. London: Academic Press, 1980.

10 Selvini MP. L'anoressia mentale. London: Chaucer Publishing Company, 1972.

11 Farmer DH. Oxford dictionary of saints. London: Oxford University Press, 1978.

12 Huysmans J-K. De Tout. 9th ed. Paris, 1903:273-80, 309-11.

13 Anonymous. Les crucifies androgynes. Moniteur de l'Archeologie, 1866: 28-9,68.

14 Gessler J. La vierge barbu. SA Brussels; L'Edition Universelle. Paris: Picard Editions, 1938.

15 Schnurer G, Ritz JM. Sankt Kummeruis und Volto Santo. Dusseldorf: Forschungen zur Volkskunde, 1934.

${ }^{16}$ Smith W, Cheetham S, eds. Dictionary of christian antiquities. Vol 2

17 Singer C. A short history of medicine. Oxford: Clarendon Press, 1928.

18 Minuchin S, Rosman BL, Baker L. Psychosomatic families: anorexia nervosa in context. Cambridge, Mass: Harvard University Press, 1978.

19 Warner M. Foan of Arc: the image of female heroism. London: Weidenfeld and Nicholson, 1981. 